\title{
$\square$
}

\section{Alt-A: The Forgotten Segment of the Mortgage Market}

\author{
Rajdeep Sengupta
}

\begin{abstract}
This study presents a brief overview of the Alt-A mortgage market with the goal of outlining broad trends in the different borrower and mortgage characteristics of Alt-A market originations between 2000 and 2006. The paper also documents the default patterns of Alt-A mortgages in terms of the various borrower and mortgage characteristics over this period. (JEL G1, G21)
\end{abstract}

Federal Reserve Bank of St. Louis Review, January/February 2010, 92(1), pp. 55-71.

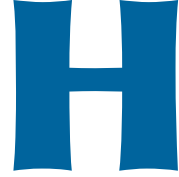

igh default rates on subprime mortgages marked the onset of the current financial crisis. Not surprisingly, both academic research and policy studies have focused their attention on the boom and subsequent collapse of the subprime mortgage market. However, the high incidence of defaults was not limited to subprime mortgages only; defaults have also risen rapidly in the other segments of the mortgage market-for example, the market for Alt-A (or Alternative-A) mortgages. But our knowledge of the Alt-A market is significantly less than our knowledge of subprime mortgages.

This paper aims to fill this void. This study presents a brief overview of Alt-A mortgage originations with the goal of outlining broad trends in the different borrower and mortgage characteristics of Alt-A originations between 2000 and 2006. The paper also documents the default patterns of Alt-A mortgages in terms of the various borrower and mortgage characteristics over this period. We begin with a broad overview of the different segments of the overall U.S. mortgage market and their evolution over this period, with a special emphasis on the Alt-A mortgage segment. ${ }^{1}$

Since the 1970s, the principal structural change in the mortgage market has been the use of securitization. Prior to this, mortgages were retained by banks in their portfolios until they matured or were paid off. Securitization is a process by which mortgages (typically a large pool of mortgages) are used as collateral to issue securities, also known as mortgage-backed securities (MBS). Some mortgage securities are backed implicitly or explicitly by the U.S. government and are commonly called agency MBS. Such origination of mortgages and issuance of MBS is dominated by loans to prime borrowers conforming to underwriting standards set by the governmentsponsored agencies. Non-agency MBS issuance can be split into three broad categories-jumbo, Alt-A, and subprime. "Loosely speaking, the Jumbo asset class includes loans to prime borrowers with an original principal balance larger than the conforming limits ${ }^{2}$ imposed on the agencies

\footnotetext{
1 See Lehnert (2009) and Quigley (2006) for a more detailed overview.

2 Conforming mortgages satisfy balance limits and are typically securitized either with some form of explicit government guarantees (Federal Housing Administration/Veterans Administration [FHA/VA] mortgages securitized by the Government National Mortgage Association [Ginnie Mae]) or with implicit government guarantees (conventional mortgages securitized by the Federal National Mortgage Association [Fannie Mae] and Federal Home Loan Mortgage Corporation [Freddie Mac]). In contrast, the privatelabel market securitizes nonconforming mortgages, which include the jumbo prime, subprime, and Alt-A markets (for more details, see Fabozzi, 2006).
} 


\section{Sengupta}

by Congress; the Alt-A asset class involves loans to borrowers with good credit but includes more aggressive underwriting than the conforming or Jumbo classes (i.e., no documentation of income, high leverage); and the Subprime asset class involves loans to borrowers with poor credit history." 3 Both agency and non-agency jumbo mortgages constitute the prime mortgage market of high-credit-quality borrowers, while the non-prime segment comprises subprime and Alt-A mortgages.

At the outset, it is important to mention that the guidelines for selecting mortgages into subprime and Alt-A pools vary by arranger of the MBS. Typically, Alt-A mortgages are underwritten to borrowers of good credit quality - that is, those who would otherwise qualify for a prime loan in terms of their credit history. However, Alt-A borrowers do not satisfy the underwriting rules for prime loans because they are unwilling or unable to provide full documentation on their mortgage application. ${ }^{4}$ Their inability to provide this information is largely due to the fact that such borrowers are in professions characterized by variable incomes or are self-employed borrowers operating cash businesses. On the other hand, subprime originations are primarily to borrowers with incomplete or impaired credit histories. Therefore, while the criterion for selection into a particular pool is not consistent across lenders, the credit quality for Alt-A pools is characteristically better than that for subprime pools.

Historically, the Alt-A market has been the preserve of highly specialized lenders with expertise in underwriting such loans. Over the years, this market has grown significantly and evolved with an increased level of investor sponsorship. Figure 1 shows the evolution of mortgage originations by market segment in the United States between 2001 and 2006. ${ }^{5}$ A significant decline in prime mortgage interest rates between 2000 and 2003 aided a refinance boom and the

3 Ashcraft and Schuermann (2008).

${ }^{4}$ Generally this documentation is regarding their income. In limited or no-documentation programs, applicants typically state their income and assets to the loan officer but are not required to show detailed proof of that information for the lender's files. They are often termed stated income mortgages.

5 This figure is updated from Sengupta and Tam (2008). increase in agency mortgages was a major factor behind the growth in total mortgage originations over this period (see Figure 1). However, with the rise in mortgage interest rates, prime originations declined sharply after 2003. Meanwhile, the growth of non-prime originations continued unabated. The growth rates in annual originations for the agency, subprime, and Alt-A segments from 2001 through 2003 were 95 percent, 94 percent, and 54 percent, respectively, but annual agency originations declined by 60 percent from 2003 to 2006. In contrast, the comparable growth rates between 2003 and 2006 for the subprime and Alt-A segments were 94 and 340 percent, respectively. The higher levels of originations after 2003 were largely sustained by the growth of the nonprime (both the subprime and Alt-A) segment of the mortgage market.

This paper uses the loan-level data on securitized Alt-A originations from 1998 through 2007 published by LoanPerformance (LP). ${ }^{6}$ The data contain details on individual securitized Alt-A loans, and a loan is classified as subprime or AltA depending on whether it is securitized in a subprime or Alt-A pool. ${ }^{7}$ The details include mortgage attributes of the loan, such as the product type, the interest rate, the loan purpose (purchase or refinance), documentation (full-doc or low-doc), loan-to-value (LTV) ratio, and borrower characteristics such as credit scores $\left(\right.$ FICO $^{8}$ at the time of origination). The next section outlines the broad trends in the underwriting standards for Alt-A mortgages in terms of these attributes. We then outline the performance of Alt-A loans in terms of the borrower and mortgage characteristics mentioned previously.

\footnotetext{
${ }^{6}$ For details on the coverage of the LP data and the relation to other available mortgage databases, see Mayer and Pence (2008). According to Mayer and Pence (2008), LP captures "around 90 percent of the subprime securitized market from 1999 to 2002 and nearly all the market from 2003 to 2005 ."

7 As mentioned earlier, different arrangers use different criteria for this selection. Therefore, it is possible that what is considered to be subprime by a particular arranger may be classified as Alt-A by a different arranger.

8 Borrower credit score at the time of loan origination is denoted by FICO (an industry standard developed by the Fair Isaac Corporation) with a number in the range 300 to 850 . The score increases with the creditworthiness of the borrower.
} 


\section{Figure 1}

\section{Origination and Issue of Mortgage Loans by Market Segment}

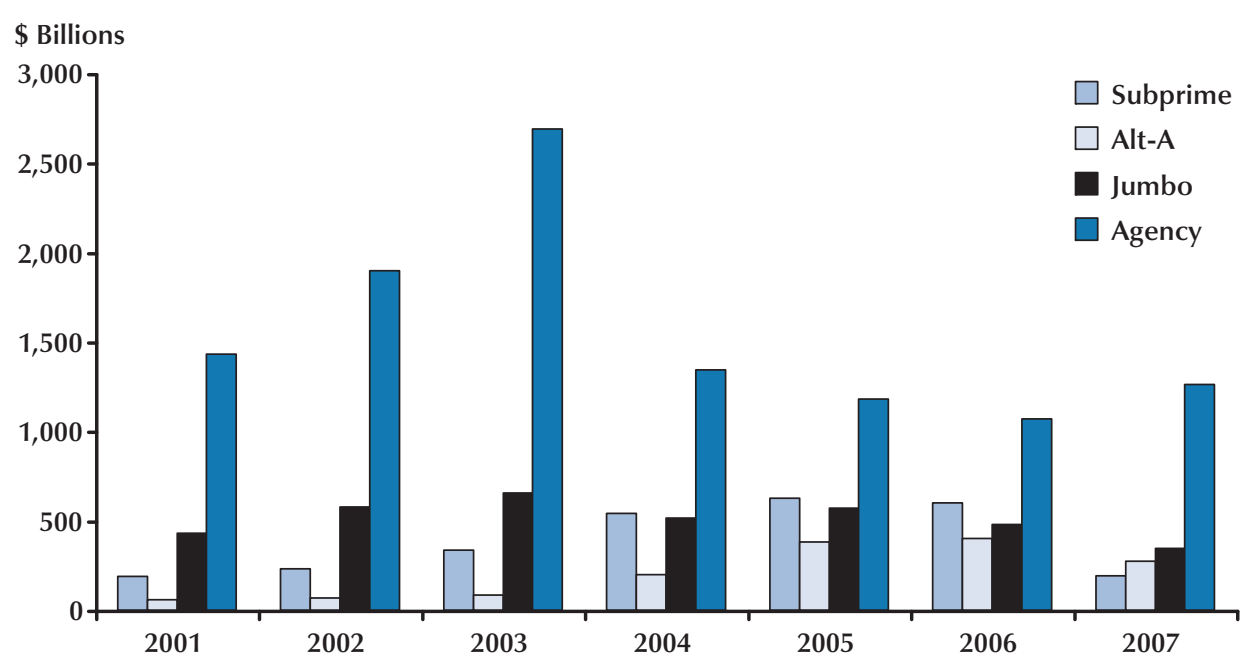

NOTE: The figure shows the evolution of mortgage originations by market segment in the United States between 2001 and 2007. SOURCE: Insider Mortgage Finance Publications, Inc.

\section{SUMMARY: TRENDS FOR ALT-A MORTGAGES}

We begin this section by studying the characteristics of Alt-A mortgages originated between 1998 through 2007. The shares of product types originated in the Alt-A markets by vintage (year of origination) are given in Table 1 . Table 1 shows that before 2004, the majority of Alt-A mortgages were fixed-rate mortgages (FRMs). Interestingly, the share of FRMs as a proportion of total originations fell by half in a single year, from 2003 to 2004. This decline was accompanied by a rise in the fraction of loans that were adjustable-rate mortgages (ARMs).

Table 1 also shows the growth of hybrid-ARM products over this period. ${ }^{9}$ We define ARMq as the hybrid-ARM where the first reset occurs after $q$ years. Typically, the mortgage rate on an ARM loan resets once every 6 months or a year into an indexed rate (like the 6-month LIBOR) plus a margin. Therefore the ARM1 is just the standard ARM product that resets after the first year, while the ARM2, ARM3, and ARM5 categories include the more specialized products, such as the $2 / 28$, the $3 / 27$, and the $5 / 25$ mortgage products, respectively. ${ }^{10}$

Table 2 presents a similar table for subprime mortgages. The data show a gradual rise in ARM2 and ARM3 products in the subprime market from around 30 percent of the market in 1998 to more than 70 percent of the market between 2004 and 2006. However, with the exception of 2004-05, ARM2 and ARM3 products were never more than 10 percent of the Alt-A market. Among hybridARM Alt-A originations, the ARM5 product has the largest share of the market, growing from less

9 Hybrid-ARM products are specialized products that include an initial period over which the repayment schedule on the mortgage resembles that of an FRM and a subsequent period over which the mortgage product acts like an ARM. During the fixed-leg of the hybrid-ARM, the mortgagee pays a lower introductory closing rate called the teaser rate. The teaser rate remains in effect until the reset date, after which the repayment schedule on the hybrid-ARM resembles an ARM. The reset date, market index rate used, and the margin are decided at the closing date.

${ }^{10}$ Therefore, the $2 / 28$ and the $3 / 27$ products are 30 -year mortgages with teaser rates for two and three years, respectively. The rationale for adopting the ARMq terminology over the traditional $2 / 28$ or $3 / 27$ is that this terminology is inclusive of mortgage products that have amortization terms of more than 30 years. 
Table 1

Evolution of Alt-A Securitized Mortgages (Percent Market Share by Product Type)

\begin{tabular}{|c|c|c|c|c|c|c|c|}
\hline \multirow[b]{2}{*}{ Vintage } & \multicolumn{6}{|c|}{ Mortgage type } & \multirow[b]{2}{*}{ Share of total } \\
\hline & FRM & ARM1 & ARM2 & ARM3 & ARM5 & Other & \\
\hline 1998 & 98.97 & 0.41 & 0.09 & 0.02 & 0.11 & 0.41 & 2.7 \\
\hline 1999 & 93.27 & 1.50 & 2.64 & 0.79 & 0.94 & 0.87 & 1.7 \\
\hline 2000 & 85.04 & 9.15 & 1.13 & 0.94 & 1.88 & 1.87 & 1.5 \\
\hline 2001 & 79.36 & 6.20 & 5.09 & 1.50 & 5.34 & 2.52 & 2.6 \\
\hline 2002 & 75.52 & 9.98 & 3.68 & 1.86 & 7.33 & 1.64 & 4.4 \\
\hline 2003 & 71.21 & 5.88 & 4.92 & 4.38 & 12.90 & 0.70 & 8.3 \\
\hline 2004 & 35.72 & 21.70 & 8.03 & 14.07 & 20.37 & 0.11 & 17.4 \\
\hline 2005 & 38.52 & 31.57 & 5.24 & 6.37 & 18.24 & 0.05 & 27.5 \\
\hline 2006 & 37.01 & 34.40 & 1.77 & 3.05 & 22.90 & 0.87 & 25.5 \\
\hline 2007 & 41.56 & 22.51 & 0.18 & 0.91 & 33.90 & 0.94 & 8.4 \\
\hline Share of total & 46.5 & 24.4 & 4.1 & 5.6 & 18.8 & 0.6 & 100 \\
\hline
\end{tabular}

NOTE: The table shows the share (percentage) of Alt-A product types by vintage (year of origination). FRM, fixed-rate mortgages; ARMq mortgages are defined as the hybrid-ARM where the first reset occurs after $q$ years. Remaining mortgage types are classified as Other.

Table 2

Evolution of Subprime Securitized Mortgages (Percent Market Share by Product Type)

\begin{tabular}{|c|c|c|c|c|c|c|c|}
\hline \multirow[b]{2}{*}{ Vintage } & \multicolumn{6}{|c|}{ Mortgage type } & \multirow[b]{2}{*}{ Share of total } \\
\hline & FRM & ARM1 & ARM2 & ARM3 & ARM5 & Other & \\
\hline 1998 & 51.33 & 8.20 & 26.53 & 4.52 & 0.25 & 9.17 & 2.6 \\
\hline 1999 & 38.88 & 2.26 & 29.34 & 19.21 & 0.50 & 9.81 & 3.8 \\
\hline 2000 & 32.58 & 1.20 & 43.29 & 14.78 & 0.56 & 7.59 & 4.1 \\
\hline 2001 & 31.70 & 0.51 & 48.69 & 12.44 & 0.54 & 6.13 & 5.1 \\
\hline 2002 & 28.37 & 0.60 & 54.84 & 12.62 & 1.16 & 2.42 & 7.7 \\
\hline 2003 & 33.57 & 0.45 & 52.60 & 11.37 & 1.20 & 0.81 & 12.9 \\
\hline 2004 & 23.81 & 0.35 & 59.73 & 14.64 & 1.30 & 0.17 & 19.5 \\
\hline 2005 & 18.66 & 0.54 & 65.48 & 13.22 & 1.57 & 0.53 & 23.0 \\
\hline 2006 & 19.98 & 0.82 & 62.56 & 10.86 & 1.35 & 3.44 & 18.1 \\
\hline 2007 & 27.59 & 0.45 & 50.23 & 9.92 & 5.87 & 5.94 & 3.4 \\
\hline Share of total & 25.7 & 0.8 & 56.7 & 12.7 & 1.6 & 2.5 & 100 \\
\hline
\end{tabular}

NOTE: The table shows the share (percentage) of subprime product types by vintage (year of origination). FRM, fixed-rate mortgages; ARMq mortgages are defined as the hybrid-ARM where the first reset occurs after $q$ years. Remaining mortgage types are classified as Other. 


\section{Figure 2}

\section{Percentage Share by Total Alt-A Origination by Purpose}

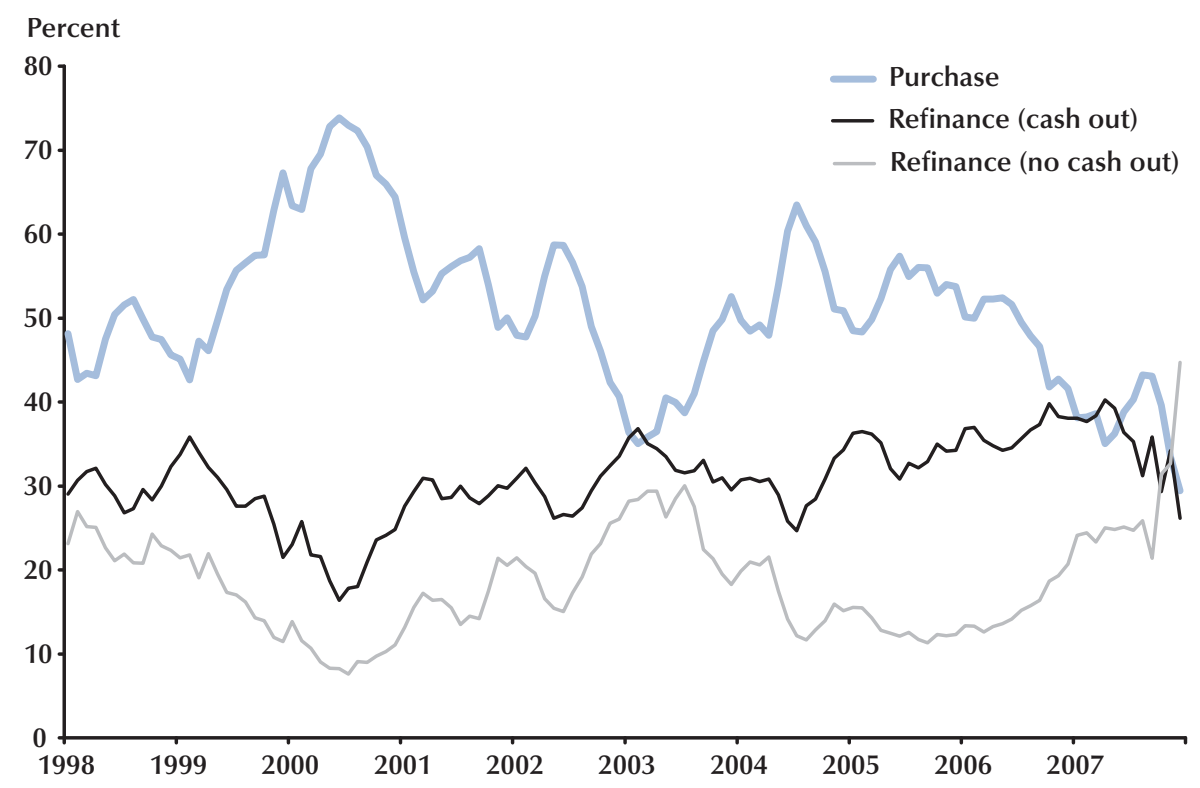

NOTE: The figure shows the monthly trends of share Alt-A originations by purpose in percentages between 1998 and 2007.

than 1 percent of the total in 1998-99 to 33 percent of the total by 2007. Further research is needed to determine the causes behind the sudden switch from FRMs to ARMs after 2003 and the increase in share of hybrid ARMs in the 2004 and 2005 vintages. This paper presents data on only Alt-A mortgages, which are then compared with the trends in subprime originations over the same period. ${ }^{11}$

It is important to point out that most hybridARM Alt-A originations are ARM5 products that originated after 2003. Therefore, most reset dates for surviving mortgages in this pool have not yet arrived at the time of this writing. In contrast, the majority of subprime hybrid-ARM originations were ARM2 and ARM3 products, which are currently past their reset dates. Therefore, unless these products are refinanced earlier, rate resets can adversely affect repayment behavior and increase future delinquency rates on surviving Alt-A originations.

\footnotetext{
${ }^{11}$ Data on the summary trends on subprime mortgages are not
} presented here but are available on request.
Figure 2 shows the monthly trends in share of Alt-A originations by purpose (purchase or refinance). Purchases make the largest category of Alt-A originations, but their proportion fluctuates over the months in our sample period. At their peak in June 2000, purchases accounted for 74 percent of Alt-A originations. However, their fraction drops to 34 percent in February 2003. This movement might be explained by the refinancing behavior of households. From 2000 to 2004, the Federal Reserve adopted an expansionary monetary policy. To the extent this translated to lower mortgage rates on Alt-A products, households would choose to refinance existing mortgages for lower rates. ${ }^{12}$

While fluctuations in the proportion of nocash-out refinances and purchases might be explained in terms of mortgage rates, this pattern does not hold for cash-out refinances. Perhaps the

\footnotetext{
12 Indeed, prime mortgage rates fell from 8.29 percent in June 2000 to 5.84 percent in March 2004. Individual mortgage rates on Alt-A loans are tailored to specific borrower and loan attributes. To the best of our knowledge, there is no known universal contract rate for Alt-A mortgages.
} 


\section{Sengupta}

\section{Figure 3}

\section{Percentage Share by Total Alt-A Origination by Occupancy}

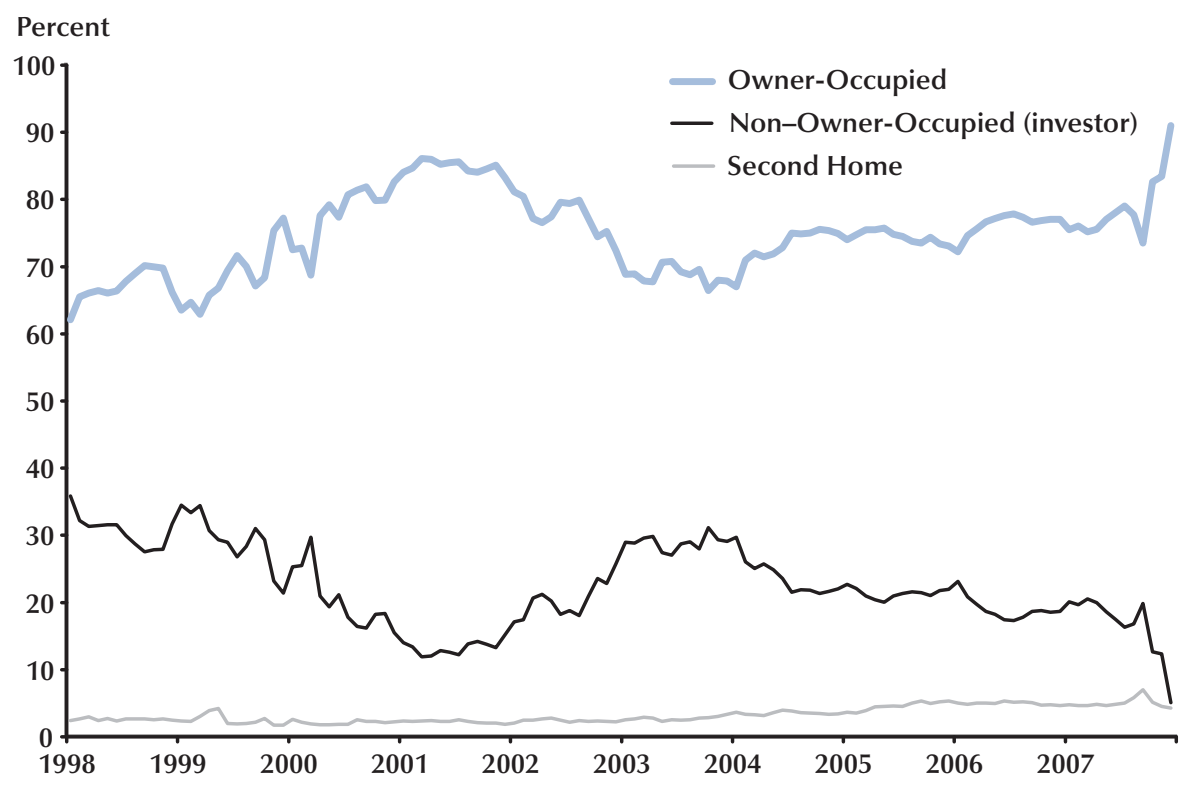

NOTE: The figure shows the monthly trends of share Alt-A originations by occupancy in percentages between 1998 and 2007.

more remarkable trend in Figure 2 is an increase in the share of cash-out refinances since 2000. A similar pattern is observed for subprime mortgages as well. In short, the growth in non-prime mortgages after 2000 has been fueled largely by households seeking to extract home equity during a period of appreciating home prices. With the decline in home prices and the onset of the mortgage crisis, the Fed lowered rates after the second quarter of 2007. At the same time, the share of both cash-out refinances and purchases fell sharply, while that for no-cash-out refinances increased.

In terms of occupancy, most Alt-A originations were for owner-occupied properties as shown in Figure 3. The share of owner-occupied housing increased from a little over 60 percent at the beginning of our sample period to more than 80 percent toward the end of the sample period. During the same time, the share of Alt-A second-home originations fell by half: from nearly 35 percent in 1998 to around 17 percent by the end of 2006. The fraction of non-owner-occupied housing has been small throughout the sample period. The broad pattern of shares in each occupancy category has been similar to that for subprime mortgages. For example, owner-occupied houses have accounted for the significant majority (more than 90 percent) of subprime originations for most of our sample period. Consequently, the share of second homes in the subprime category has been much smaller than that for Alt-A.

Figure 4 shows a sharp increase in the share of low-doc loans in post-2004 Alt-A originations. Barring a few exceptions, the share of low-doc originations has always ranged between 50 and 60 percent of originations until 2004. To the casual observer this figure may seem very high. But this is precisely the rationale behind the creation of the Alt-A market: borrowers of good credit quality unwilling or unable to provide full documentation for a prime loan. In any case, the share of lowdoc loans rose from 52 percent in April 2004 to 78 percent by the end of 2006. A similar trend toward low-doc originations was witnessed for 


\section{Figure 4}

\section{Percentage Share by Total Alt-A Origination by Documentation}

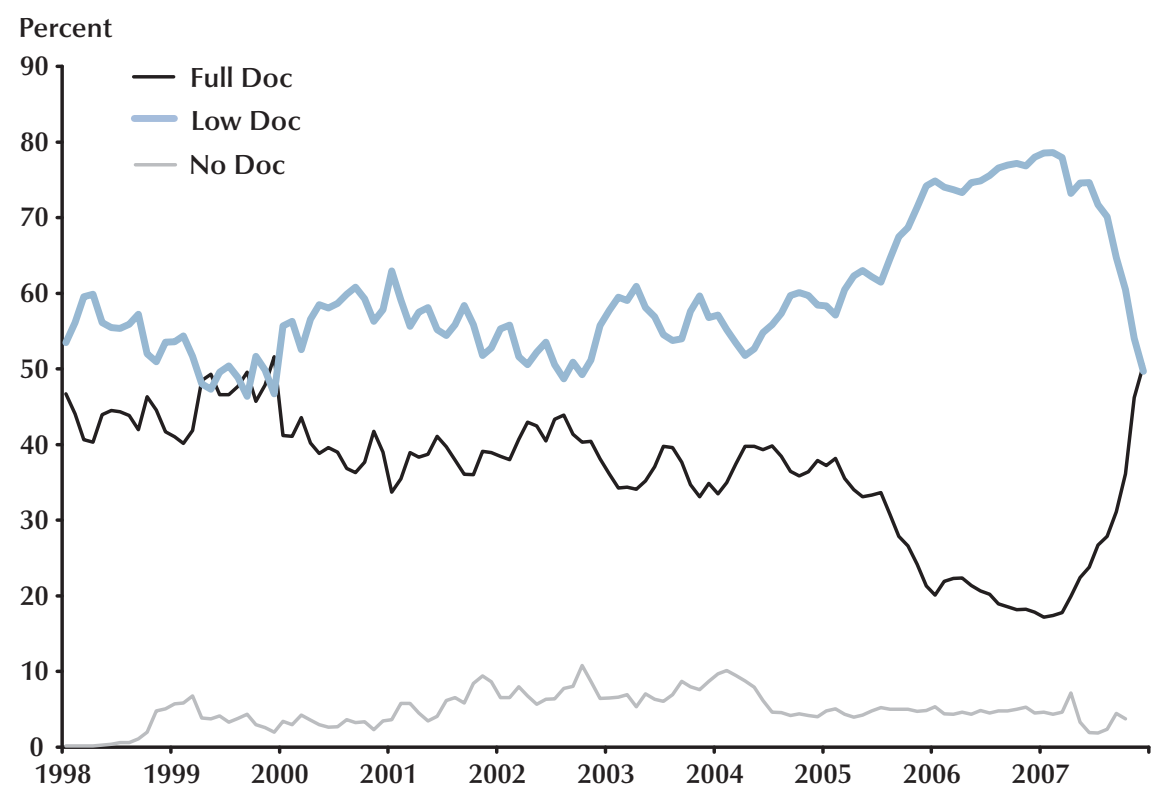

NOTE: The figure shows the monthly trends of share Alt-A originations by documentation in percentages between 1998 and 2007.

subprime originations, although the increase there was moderate and gradual compared with that of Alt-A. It is unclear what prompted this sharp increase in low-doc originations in the nonprime market segment. More recently, the share of low-doc mortgages dropped sharply from its peak of 78 percent at the beginning of 2007 to 50 percent at the end of 2007.

An important measure of underwriting is the credit quality on the originations as represented by the credit (FICO) scores of borrowers at the time of origination. The majority of borrowers who originate Alt-A mortgages have FICO scores in excess of 680 (Figure 5). This is a major distinguishing characteristic between the subprime and Alt-A mortgage pools. The average credit quality of Alt-A pools is significantly higher than that for subprime pools. It needs to be mentioned here that this is not the only distinguishing characteristic; it is often possible to identify a mortgage that belongs to the subprime pool but has a FICO score above 700 . The reason a mortgage with a high FICO score could be characterized as subprime (and not Alt-A) is possibly because the mortgage fails to qualify as Alt-A (or even prime) on one or more criteria other than credit score such as documentation, lien type, and LTV ratio. ${ }^{13}$

Figure 5 shows that, for the most part, the shares of originations with FICO scores in the 621-680 range and the 740 or higher range have been similar. The share of originations with FICO scores above 740 fell for a period between October 1998 and December 1999; this was accompanied by a rise in the share of originations in the 621-680 range. More recently, the onset of defaults in nonprime mortgages tightened lending standards in this market, leading to a sharp increase in the percentage of originations with FICO scores in excess of 740 from around 26 percent in December 2006 to 54 percent in November 2007. To sum up, Figure 5 shows that, except for the two periods mentioned above, the share of originations across

\footnotetext{
${ }^{13}$ The choice of a non-prime mortgage between Alt-A and subprime
} typically varies with the arranger of the security. 


\section{Sengupta}

\section{Figure 5}

\section{Percentage Share by Total Alt-A Origination by Credit Quality (FICO Score)}

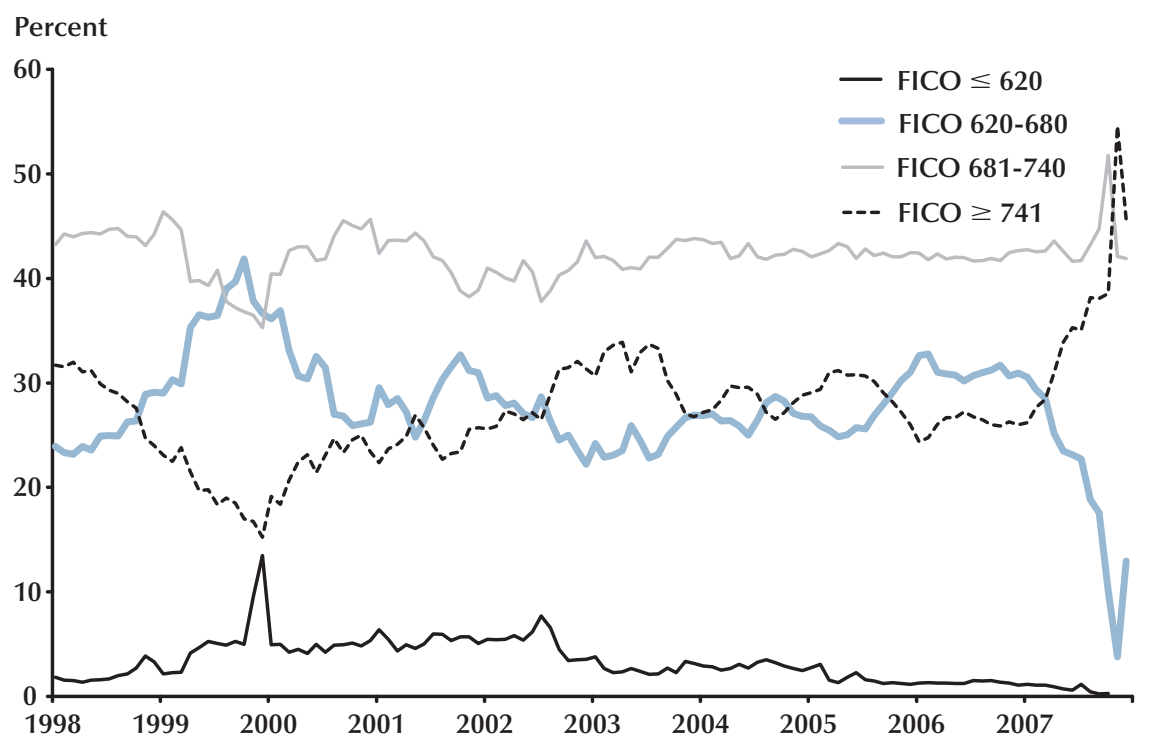

NOTE: The figure shows the monthly trends of share Alt-A originations by credit quality in percentages between 1998 and 2007.

the various FICO score categories are fairly stable over the years in our sample period.

At this point, it is important to highlight the difference between the originations of subprime and Alt-A loans between 2000 and 2007 with regard to documentation and credit scores. In both cases, the share of low-doc loans increased over the years, as shown in Figure 6. However, in the case of the subprime market, there is evidence that average credit scores on originations with lower documentation increased. This is shown in Figure 6B as the decline in the proportion of low-doc originations with FICO scores less than 620. This feature of underwriting suggests that lenders' emphasis on FICO score was not only an adequate indicator of credit risk, but also a means to adjust for other riskier attributes on the origination. On the other hand, there does not appear to be such a trend toward higher FICO scores for loans with low documentation in the case of the Alt-A mortgage market. The proportion of low-doc loans with FICO scores less than 680 remains roughly the same over the years in our sample period (Figure 6A). ${ }^{14}$ This pattern seems to point to secular deterioration in the underwriting for Alt-A mortgages, unlike that observed for subprime originations.

A final measure of underwriting on Alt-A originations in our dataset is the LTV ratio on the mortgage (Figure 7). ${ }^{15}$ The majority of Alt-A originations have LTV ratios that are less than 80 percent, and it is important to note that the LTV threshold of 80 percent is one of the requirements on prime mortgages. Figure 7 shows that the share of originations with LTVs less than or equal to 80 percent has declined over the years in our sample period. This is accompanied by an increase in the

\footnotetext{
${ }^{14}$ The FICO scores chosen are higher for Alt-A because on average Alt-A credit scores are higher than subprime. The weighted average of FICO scores for the Alt-A market is presumably higher, but we have chosen our cutoff conservatively.

${ }^{15}$ The LTV ratio is calculated as the closing balance/value of the property, and where available we have used the cumulative loanto-value (CLTV) ratio because it provides a better measure of the home equity of the borrower. The CLTV ratio is the proportion of loans (secured by the property) on all liens in relation to the property's value.
} 
Figure 6

\section{Evidence on Underwriting: Documentation and FICO Score}

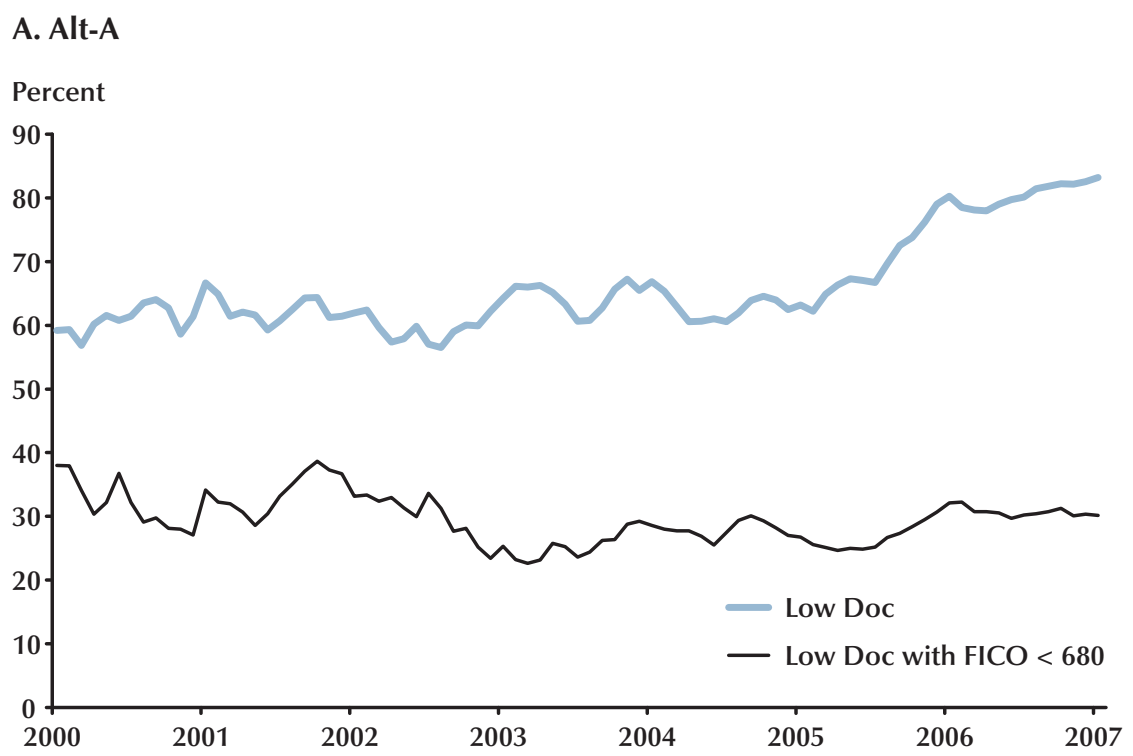

\section{B. Subprime}

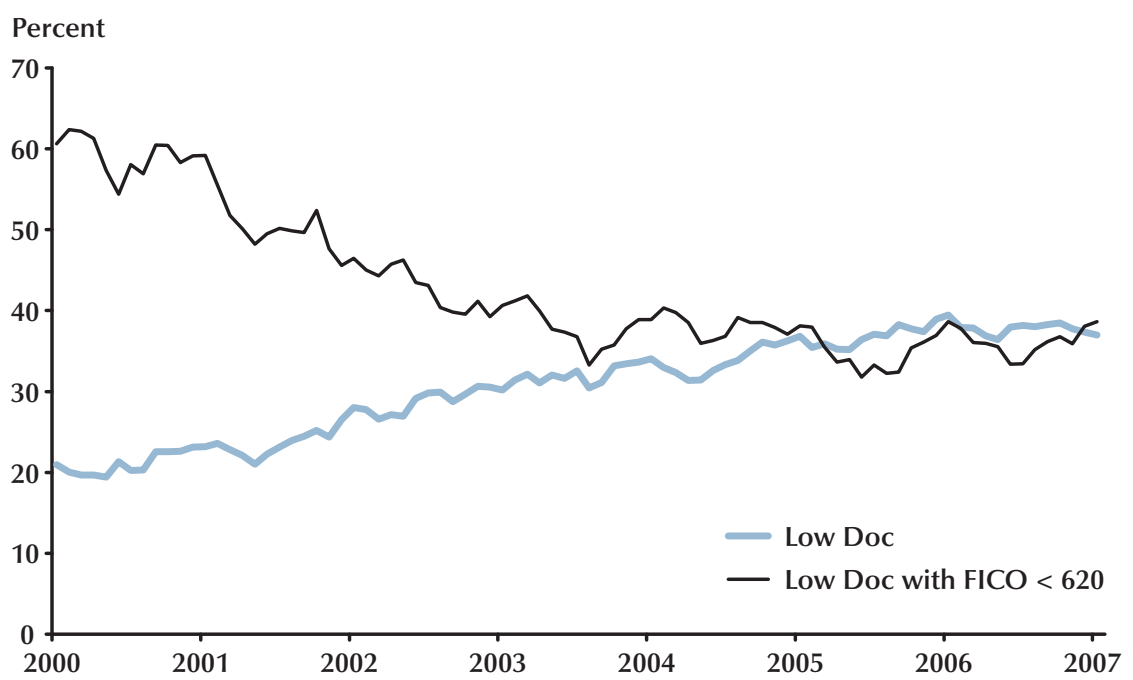

NOTE: The figure shows the monthly trends of share Alt-A (subprime) originations with low documentation, and among those, with FICO scores less than 680 (620) in percentages between 2000 and 2007. 


\section{Sengupta}

\section{Figure 7}

\section{Percentage Share by Total Alt-A Origination by LTV Ratios}

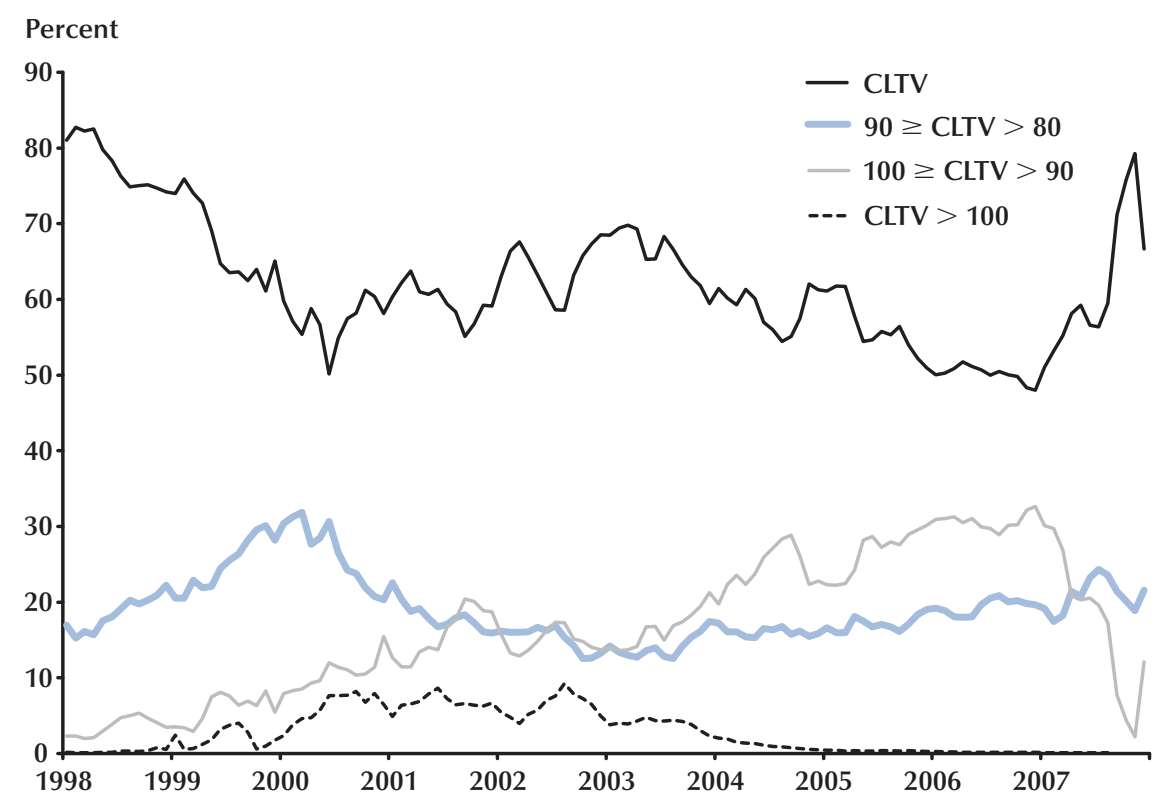

NOTE: The figure shows the monthly trends of share Alt-A originations by loan-to-value ratios in percentages between 1998 and 2007.

share of Alt-A originations with LTV in the (90, 100] range. The share in this category increased from a low of 2 percent of total originations from the beginning of our sample period to about 32 percent by the end of 2006. Meanwhile, the share of originations with LTV in the intermediate range of $(80,90]$ has remained fairly stable except for a period between 1999 and 2001 when this share increased.

In summary, Alt-A mortgages are typically originated to borrowers of moderate to high credit quality with a lack of willingness or ability to provide documentation in support of their loan application. First, most Alt-A originations have FICO scores above 680. At the same time, the share of low-doc originations in this market has almost never been below 50 percent. While this has been the principal characteristic of Alt-A loans, the market witnessed a significant relaxing of credit standards both in terms of a greater share of lowdocumentation loans and high-LTV originations between 2000 and 2006. Perhaps more signifi- cantly, the share of borrowers using Alt-A products to extract equity in their homes has almost doubled between 2000 and 2006. In the next section, we study the performance of these mortgages in terms of the attributes on the originations.

\section{Loan Performance of Alt-A Mortgages}

The LP data allow for tracking repayment behavior on mortgages on a monthly basis. Therefore, we can determine the nature (30-day, 60-day, 90-day, or foreclosure) and timing (month) of the delinquency event. Following industry conventions, we define a mortgage to be in default (or in serious delinquency) if it records a 90-day delinquency event at any point in its repayment history. ${ }^{16}$ The nonparametric default probabilities presented in this paper are calculated using the Kaplan-Meier product limit estimator (see the appendix for details on this methodology).

\footnotetext{
${ }^{16}$ Although we use 90-day delinquencies throughout the paper, the results for 60-day delinquencies and foreclosures are qualitatively similar and are available on request.
} 


\section{Figure 8}

\section{Default Rate on Alt-A Originations by Vintage}

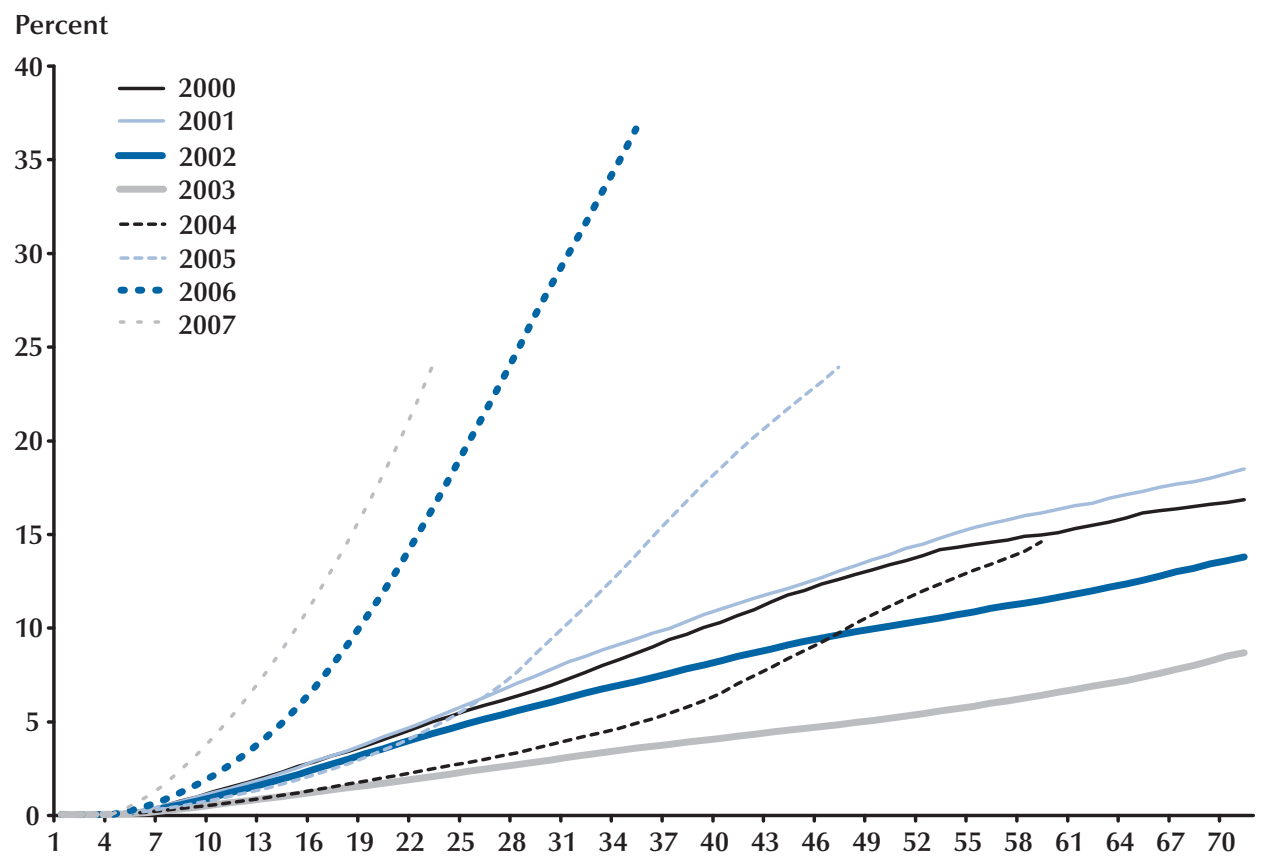

NOTE: The plot shows the Kaplan-Meier default probabilities by loan age for securitized Alt-A mortgages. The graph presents the default probabilities by years of origination (vintage). Each line shows the performance of originations of the same vintage.

Figure 8 presents the overall performance of Alt-A mortgages by showing estimated default probabilities for each vintage (year of origination) by age of the loan. The broad trends in Figure 8 show that defaults started to rise sharply in 2006 and 2007, primarily for originations after 2003. To give an example, about 10 percent of mortgages originated in 2001 were in serious delinquency after the third calendar year (at the beginning of 2003), whereas the same proportion of defaults for 2006 originations occurred after the first oneand-a-half calendar years (middle of calendar year 2007). ${ }^{17}$

The rise in sharp defaults for later vintages is best viewed by comparing the default rates on originations of 2003 and 2004 vintages with that

\footnotetext{
${ }^{17}$ The year of origination is counted as the first year of evaluation of loan performance. In the interest of clarity, the performance plots for 1998 and 1999 vintages are omitted from Figure 8.
}

of originations of 2005 and 2006 vintages. Table 3 shows the default rates on originations of 2003 and 2004 vintages at the end of the second calendar year were 2.03 percent and 2.47 percent, respectively. In contrast, originations of 2006 vintage had a default rate of 16.36 percent by the end of the second calendar year. To summarize, defaults rise sharply around 2006 and this is largely concentrated on originations after 2003. Perhaps the most striking feature of this trend is that a significant proportion of the mortgages defaulted very early. This is also true for subprime mortgages, and the literature on subprime has focused on explaining such high early defaults.

An interesting piece of anecdotal evidence is revealed in the significantly lower default rates on 2003 vintages. Indeed, 2003 is the best-performing vintage for Alt-A mortgages and this is true for subprime mortgages as well. For subprime originations, the anomalous behavior for originations 
Table 3

Performance of 2003-2006 Alt-A Vintages for the First Three Calendar Years

\begin{tabular}{lcccc} 
& \multicolumn{5}{c}{ Default rate (\%) per year of origination } \\
\cline { 2 - 5 } Calendar date & 2003 & 2004 & 2005 & 2006 \\
\hline End of 2003 & 0.64 & - & - & - \\
End of 2004 & 2.03 & 0.63 & - & - \\
End of 2005 & 3.55 & 2.45 & 0.97 & - \\
End of 2006 & - & 4.86 & 4.67 & 2.66 \\
End of 2007 & - & - & 13.84 & 16.36 \\
End of 2008 & - & - & - & 36.60
\end{tabular}

The table shows the default rates on Alt-A mortgages originated between 2003 and 2006 at the end of the first three calendar years.

Table 4

90-Day Delinquent Alt-A Mortgages (Percent by Attributes on Origination)

\begin{tabular}{|c|c|c|c|c|c|c|c|c|}
\hline \multirow[b]{2}{*}{ All } & \multicolumn{3}{|c|}{ Product type } & \multicolumn{2}{|r|}{ Purpose } & \multicolumn{3}{|c|}{ Occupancy } \\
\hline & FRM & ARM & ARM5 & Purchase & $\begin{array}{l}\text { Refinance Refinance } \\
\text { (cash-out) (no cash-out) }\end{array}$ & Owner & $\begin{array}{l}\text { Second } \\
\text { home }\end{array}$ & $\begin{array}{c}\text { Non-owner } \\
\text { (investor) }\end{array}$ \\
\hline
\end{tabular}

A. Percent delinquent after first 18 calendar months

$\begin{array}{rrrrrrrrrrr}2000 & 3.1 & 3.5 & 0.4 & 0.7 & 3.3 & 2.6 & 3.1 & 3.3 & 1.5 & 2.6 \\ 2001 & 3.1 & 3.1 & 2.7 & 1.2 & 3.9 & 2.3 & 2.0 & 3.0 & 1.8 & 3.9 \\ 2002 & 2.7 & 2.7 & 2.4 & 1.5 & 3.4 & 2.2 & 1.5 & 2.8 & 2.1 & 2.2 \\ 2003 & 1.3 & 1.2 & 1.7 & 1.0 & 1.9 & 1.1 & 0.7 & 1.6 & 1.0 & 0.7 \\ 2004 & 1.5 & 1.4 & 1.5 & 1.0 & 1.7 & 1.2 & 1.3 & 1.6 & 0.9 & 1.3 \\ 2005 & 2.4 & 1.9 & 2.8 & 3.2 & 2.9 & 1.7 & 2.2 & 2.4 & 1.8 & 2.6 \\ 2006 & 7.9 & 5.6 & 9.3 & 12.9 & 9.5 & 5.3 & 9.0 & 8.0 & 6.7 & 7.8 \\ 2007 & 13.1 & 8.4 & 16.6 & 18.8 & 16.6 & 8.9 & 14.1 & 13.3 & 13.9 & 11.8\end{array}$

B. Percent delinquent after two calendar years

$\begin{array}{rrrrrrrrrrr}2000 & 5.0 & 5.5 & 1.1 & 2.2 & 5.1 & 4.1 & 5.1 & 4.8 & 2.7 & 4.4 \\ 2001 & 5.1 & 5.2 & 4.3 & 2.3 & 6.3 & 3.9 & 3.5 & 4.7 & 3.1 & 5.9 \\ 2002 & 4.3 & 4.5 & 3.4 & 2.3 & 5.4 & 3.7 & 2.6 & 4.3 & 3.2 & 3.5 \\ 2003 & 2.0 & 1.8 & 2.5 & 1.5 & 2.9 & 1.7 & 1.1 & 2.3 & 1.4 & 1.2 \\ 2004 & 2.4 & 2.3 & 2.6 & 1.8 & 2.7 & 2.1 & 2.3 & 2.4 & 1.5 & 2.2 \\ 2005 & 4.7 & 3.3 & 5.7 & 5.9 & 5.5 & 3.5 & 4.3 & 4.2 & 3.8 & 4.9 \\ 2006 & 16.4 & 10.7 & 19.9 & 24.2 & 18.5 & 12.4 & 18.8 & 15.0 & 14.8 & 15.6 \\ 2007 & 24.0 & 15.7 & 30.3 & 33.0 & 28.6 & 18.2 & 26.0 & 22.4 & 24.0 & 22.0\end{array}$

The table shows the percentage of originations of a given vintage that are in default within a given time period across various attributes on the origination, including product types, purpose, and occupancy. 
Table 5

90-day Delinquent Alt-A Mortgages (Percent by Attributes on Origination)

\begin{tabular}{|c|c|c|c|c|c|c|c|c|c|c|}
\hline & \multirow[b]{2}{*}{ All } & \multicolumn{2}{|c|}{ Documentation } & \multicolumn{3}{|c|}{ Credit score } & \multicolumn{4}{|c|}{ CLTV ratio } \\
\hline & & Full & Low & $621-680$ & $681-740$ & $740+$ & $<70$ & {$[70,80)$} & $(80,90]$ & $(90,100]$ \\
\hline \multicolumn{11}{|c|}{ A. Percent delinquent after first 18 calendar months } \\
\hline 2000 & 3.1 & 2.4 & 3.6 & 5.1 & 2.1 & 1.2 & 1.3 & 2.5 & 5.1 & 4.2 \\
\hline 2001 & 3.1 & 1.9 & 3.9 & 5.5 & 2.0 & 1.1 & 1.3 & 2.4 & 5.5 & 5.2 \\
\hline 2002 & 2.7 & 1.9 & 3.3 & 4.9 & 1.8 & 0.8 & 0.9 & 2.2 & 4.4 & 5.1 \\
\hline 2003 & 1.3 & 0.9 & 1.6 & 2.8 & 0.9 & 0.4 & 0.4 & 0.9 & 2.3 & 3.1 \\
\hline 2004 & 1.5 & 1.1 & 1.7 & 2.7 & 1.2 & 0.5 & 0.5 & 1.0 & 2.2 & 2.7 \\
\hline 2005 & 2.4 & 1.6 & 2.8 & 4.3 & 2.2 & 0.9 & 0.7 & 1.5 & 2.8 & 4.8 \\
\hline 2006 & 7.9 & 3.6 & 9.1 & 12.1 & 7.8 & 3.4 & 1.7 & 4.8 & 9.5 & 14.1 \\
\hline 2007 & 13.1 & 5.8 & 14.9 & 19.3 & 14.0 & 6.4 & 3.0 & 9.3 & 18.1 & 23.6 \\
\hline \multicolumn{11}{|c|}{ B. Percent delinquent after two calendar years } \\
\hline 2000 & 5.0 & 4.1 & 5.5 & 7.8 & 3.6 & 2.0 & 2.2 & 4.1 & 7.9 & 6.4 \\
\hline 2001 & 5.1 & 3.4 & 6.3 & 8.7 & 3.5 & 1.8 & 2.2 & 4.0 & 8.5 & 8.7 \\
\hline 2002 & 4.3 & 3.3 & 5.1 & 8.0 & 3.0 & 1.2 & 1.5 & 3.6 & 6.9 & 8.1 \\
\hline 2003 & 2.0 & 1.5 & 2.3 & 4.3 & 1.5 & 0.6 & 0.6 & 1.5 & 3.6 & 4.6 \\
\hline 2004 & 2.4 & 1.9 & 2.8 & 4.5 & 2.0 & 0.9 & 1.0 & 1.7 & 3.6 & 4.2 \\
\hline 2005 & 4.7 & 2.9 & 5.5 & 8.2 & 4.4 & 1.8 & 1.4 & 3.1 & 6.1 & 8.7 \\
\hline 2006 & 16.4 & 7.7 & 18.7 & 23.6 & 16.5 & 7.7 & 4.2 & 11.5 & 21.7 & 25.4 \\
\hline 2007 & 24.0 & 11.5 & 27.0 & 34.2 & 25.6 & 12.3 & 7.1 & 19.2 & 33.3 & 37.9 \\
\hline
\end{tabular}

The table shows the percentage of originations of a given vintage that are in default within a given time period across various attributes on the origination, including documentation, credit score, and CLTV ratio.

of 2003 vintage has been explained in terms of the high prepayment rates on subprime mortgages. As many as 83 percent of surviving subprime hybrid-ARMs that were originated in 2003 were prepaid by the end of 2007 (see Bhardwaj and Sengupta, 2009b). This is not surprising for subprime mortgages, given that prepayment is an integral part of the mortgage design for hybrid-ARM products (see Gorton, 2008, for details). However, hybrid-ARMs are not a significantly large part of the Alt-A pool. Therefore, it would be interesting to explore whether the low default rates on 2003 Alt-A products were also driven by high prepayments. In what follows, we show that this broad trend of a significant increase in the default rates on post-2004 originations can be seen across various mortgage attributes such as product type, purpose, occupancy, and documentation. These trends show a high degree of correlation between default rates and some origination attributes. Of course, the standard caveat applies to interpreting these correlations as causation.

Tables 4 and 5 show the percentage of originations of a given vintage that are in default within a given time period, by various attributes of the origination. Panel A presents the default rates for the first 18 calendar months since the year of origination, whereas Panel B reports the same for the first two years since the year of origination. These choices of time periods are driven by two reasons. First, we have only the first two years of data for every origination vintage from 2000 through 2007, allowing for a comparison across all vintages. Second, as demonstrated earlier, the crisis in the mortgage markets was characterized by high early defaults. 


\section{Sengupta}

For most years in our sample period, ARMs have registered higher default rates than FRMs, but the difference was much greater for originations between 2005 and 2007 (columns 3 through 5 in Table 4). For 2003, however, the performance of ARMs is similar to that of FRMs. The lower default rates on ARMs for earlier vintages might be explained by the low interest rate environment during the early part of this decade. However, as the Federal Reserve tightened monetary policy after the second half of 2004, the burden of interest payments on ARMs would have increased significantly. Also, the share of ARMs in total originations for earlier vintages was low compared with the share for later vintages. Therefore, it is difficult to interpret the default patterns as being reflective of the risk underlying each product type. Evidently, the default rates on ARM5 products ${ }^{18}$ are even higher than those on ARM products overall. This is interesting, given that the loan maturity period under consideration is well before the reset dates on the ARM5 products. These results seem to suggest that the defaults on Alt-A products have little to do with interest rate resets on hybrid-ARM products.

Next, we study the default patterns by purpose of origination (columns 6 through 8 in Table 4). Purchase originations show significantly higher rates of default over the years in our sample period. This may be attributed to greater adverse selection problems for first-time buyers than for refinances, where the borrower is likely to have had a recorded history of mortgage payments, presumably with the same lender. Here, too, default rates rise significantly for originations after 2005.

Under occupancy, we find that non-owneroccupied homes have the highest default rates, followed by second homes, while owner-occupied homes have the lowest default rates (columns 9 through 11 in Table 4). Anecdotal evidence often points to the role of investors using non-prime mortgage products to speculate on residential property after 2004 . This has been claimed as a proximate cause of the mortgage crisis in the United States. Of course, this would also explain

\footnotetext{
18 The choice of ARM5 is motivated by the fact that, among Alt-A originations with hybrid products, the ARM5 product has the largest market share.
}

the deterioration of lending standards and the high early default rates on originations after 2004 . However, the summary data presented above show little evidence in support of this hypothesis. The proportion of second homes had been declining over the sample period. Moreover, non-owneroccupied properties were a small fraction of the loans throughout the sample period.

Not surprisingly, low-doc originations show a higher rate of default than full-doc loans (columns 3 and 4 in Table 5). Given the higher default rates on such loans, even for the earlier vintages, it is surprising to see the increasing share of Alt-A originations after 2004 that do not provide full documentation. To most observers this would bring into question the wisdom of originators who increased the proportion of lowdoc loans in their mortgage pools. However, as noted previously, Alt-A mortgages are originated in an effort to capture borrowers who have good credit but are otherwise unable to provide documentation on their loans. Moreover, it is difficult to interpret the lack of documentation on loans as the principal cause behind the high default rates in the Alt-A market. For example, more than half of the originations in 2003 were loans without full documentation. However, the difference in the default rates on full-doc and low-doc loans for this vintage was less than 1 percentage point even after three calendar years. ${ }^{19}$

Next, we turn our attention to default rates in terms of credit quality as measured by borrower FICO at the time of origination (columns 5 through 7 in Table 5). A number of observers have pointed to higher default rates on a given FICO score as an indication of the poor performance of FICO. However, one needs to approach this argument with caution. For instance, if some exogenous factor were driving defaults in the mortgage market, one is likely to see poor performance for the said vintages across all FICO score groups. This is precisely what we observe in the data. A more relevant test of the effectiveness of FICO would

\footnotetext{
19 Among originations of 2003 vintage, the default rate after three calendar years on full-doc loans was 2.82 percent, whereas the default rate on low-doc loans was 3.79 percent. The comparable figures for originations of 2006 vintage were 19.03 and 39.18 percent, respectively.
} 
be a comparison across the different FICO score groups for a given vintage. The three panels show the performance of Alt-A by FICO score groups of 621-680, 681-740, and higher than 740. ${ }^{20}$ Within each FICO score group, the later vintages (post2004 originations) show higher default rates. More importantly, across the various score groups, the default rates for the same vintage are higher as one moves from a higher FICO score group to a lower FICO group.

Lastly, we study the effect of LTV on the summary measures of default (columns 8 through 11 in Table 5). Default probabilities increase when one moves from originations with lower LTV ratios to those with higher LTV ratios. Note that the loan performance for the 80 to 90 percent and the 90 to 100 percent LTV ratio categories are somewhat similar, especially for the early vintages. ${ }^{21}$ However, the gap in the default rates widens on later vintages.

In summary, Tables 4 and 5 confirm our a priori knowledge on underwriting. First, riskier attributes such as lower documentation, lower FICO scores, and higher LTV ratios perform poorly. Second, the differences in default probabilities between a more-risky attribute and that of a lessrisky attribute increase for originations after 2004. Third, there is no monotonic trend over the years in the default rates across these attributes, however. Default rates have typically fallen for 2003 and 2004 originations, but risen sharply for later vintages. Finally, even for the later vintages, the defaults have risen across all attributes, irrespective of ex ante risk on the attribute. These summary results emphasize that one must exert caution when interpreting the riskier attributes on the origination as proximate causes of high early defaults on Alt-A mortgages in 2006 and 2007.

\section{CONCLUSION}

This paper provides a preliminary overview of Alt-A mortgages that were originated in the United States from 1998 through 2007. First, the summary data indicate a shift of Alt-A originations toward a greater share of owner-occupied properties, adjustable-rate products, and cash-out refinances. This is accompanied by a deterioration of underwriting standards for a greater proportion of mortgages with lower documentation and higher loan-to-value ratios. Serious delinquencies on Alt-A originations rose sharply in 2006 and 2007, primarily for originations after 2003. Even for originations of a later vintage, the defaults have risen across all attributes, irrespective of ex ante risk on the attribute.

A final comment addresses the following question: How does one reconcile the secular deterioration of underwriting for Alt-A mortgages with the lack of this evidence in the case of subprime mortgages (see Bhardwaj and Sengupta, 2009a)? In their handbook chapter on Alt-A mortgages, Bhattacharya, Berliner, and Liber (2006, p. 189) remark that "the demarcation between Alt-A and subprime loans has been blurred. Over time Alt-A has expanded to include loans with progressively less documentation and lower borrower credit scores. At the same time, subprime loans have, on average experienced a slow but steady rise in average credit scores. A result of this convergence has been the creation of the so-called Alt-B sector, where loans using this nomenclature were securitized in 2004."

\footnotetext{
${ }^{20}$ We do not report default rates for the FICO score group less than 620 , as their share throughout has been small and declining. In fact, fewer than 1 percent of post-2004 originations in the Alt-A market have FICO scores less than 620 .

21 Again, since they form a small share of the total market, the plots for Alt-A originations with LTV in excess of 100 are not reported here.
} 


\section{Sengupta}

\section{REFERENCES}

Ashcraft, Adam B. and Schuermann, Til. "Understanding the Securitization of Subprime Mortgage Credit." Staff Reports No. 318, Federal Reserve Bank of New York, March 2008; www.newyorkfed.org/research/staff reports/sr318.pdf.

Bhardwaj, Geetesh and Sengupta, Rajdeep. "Where's the Smoking Gun? A Study of Underwriting Standards for US Subprime Mortgages.” Working Paper 2008-036C, Federal Reserve Bank of St. Louis, October 1, 2009a; http://research.stlouisfed.org/wp/2008/2008-036.pdf.

Bhardwaj, Geetesh and Sengupta, Rajdeep. “Did Prepayments Sustain the Subprime Market?” Working Paper 2008-039B, Federal Reserve Bank of St. Louis, May 2009b; http://research.stlouisfed.org/wp/2008/2008-039.pdf.

Bhattacharya, Anand K.; Berliner, William S. and Lieber, Jonathan. "Alt-A Mortgages and MBS,” in Fabozzi, Frank, ed., The Handbook of Mortgage-Backed Securities. Sixth edition. New York: McGraw-Hill, 2006, pp. 187-206.

Fabozzi, Frank J., ed. The Handbook of Mortgage-Backed Securities. Sixth edition. New York: McGraw-Hill, 2006.

Gorton, Gary. "The Panic of 2007.” Manuscript prepared for the Federal Reserve Bank of Kansas City, Jackson Hole Conference, August 4, 2008; www.kc.frb.org/publicat/sympos/2008/gorton.08.04.08.pdf.

Kaplan, E. and Meier, P. “Nonparametric Estimation from Incomplete Observations.” Journal of the American Statistical Association, 1958, 53(282), pp. 457-81.

Lehnert, Andreas. "Residential Mortgages," in Allen Berger, Phillip Molyneux, and John Wilson, eds., Oxford Handbook of Banking. Oxford, UK: Oxford University Press, 2009.

Mayer, Christopher K. and Pence, Karen. "Subprime Mortgages: What, Where, and to Whom?” Working Paper No. W14083, National Bureau of Economic Research, June 2008; http://papers.nber.org/papers/w14083.pdf.

Quigley, John M. "Federal Credit and Insurance Programs: Housing.” Federal Reserve Bank of St. Louis Review, July/August 2006, 88(4), pp. 281-309; http://research.stlouisfed.org/publications/review/06/07/Quigley.pdf.

Sengupta, Rajdeep and Tam, Yu Man. "Mortgage Originations: 2000-2006.” Federal Reserve Bank of St. Louis Economic Synopses, 2008, No. 18; http://research.stlouisfed.org/publications/es/08/ES0818.pdf. 


\section{APPENDIX}

Default rates and the probability of surviving a delinquency are calculated by using the Kaplan and Meier (1958) product limit estimator. We begin this nonparametric approach to survival and hazard function estimation by formalizing it in the current context of mortgage repayment behavior.

Following Kaplan and Meier (1958), the delinquency rate $D(t)$ at month $t$ (the age of the mortgage in months) is defined as

$$
D(t)=1-P(T>t)
$$

where $T$ is the age in months for the delinquency event (60-day, 90-day, or foreclosure) of a randomly selected mortgage and $S(t) \equiv P(T>t)$ is the survivor function or the probability of surviving the delinquency event beyond age $t$. Let $t_{(1)}<t_{(2)}<\cdots<t_{(k)}$ represent the ordered age in months at the time of the delinquency event. For all these months, let $n_{(i)}$ be the number of surviving mortgages just prior to month $t_{(i)}$. Surviving mortgages exclude not only the ones that have been delinquent, but also the ones that have been refinanced prior to age $t_{(i)}$. If $d_{(t)}$ is the number of mortgages that become delinquent at age $t_{(i)}$, then the Kaplan-Meier estimator of surviving the event of delinquency is defined as

$$
\hat{P}(T>t)=\prod_{i=1}^{k}\left(1-\frac{d_{i}}{n_{i}}\right) .
$$


